\title{
Metabolic responses and $\beta$-carotene production by the unicellular green alga Dunaliella salina exposed to leaf extracts
}

\author{
Alireza Einali ${ }^{\star}{ }^{\star}$, Sahar Mazang-Ghasemi', Jafar Valizadeh'and Meisam Noorozifar ${ }^{2}$
}

Received: January 1, 2017

Accepted: February 23, 2017

\begin{abstract}
The present work investigated the effects of aqueous extracts of eucalyptus (Eucalyptus globulus) and elderberry (Sambucus ebulus) leaves on $\beta$-carotene productivity in Dunaliella salina, a green microalga. Leaf extracts from eucalyptus have greater amounts of phenolics and flavonoids, as well as greater ferric reducing antioxidant potential than elderberry. The extracts of both species greatly inhibited growth of algal suspensions. However, chlorophyll and $\beta$-carotene concentration increased in cells treated with leaf extracts, and the highest values were detected in $1 \%$ eucalyptus and $2 \%$ elderberry extracts. Fresh weight, total sugar, and protein content significantly increased following exposure of cells to different doses of leaf extracts. However, in doses containing more than $2 \%$ eucalyptus, the upward trend for total sugar and protein ceased and remained statistically unchanged. These results suggest that metabolic modifications enable $D$. salina cells to tolerate the stress induced by the leaf extracts through allocating carbon flux to the synthesis of osmolytes and putative antioxidant molecules (e.g. sugars and $\beta$-carotene). Therefore, the use of leaf extracts holds potential to be a promising and effective way to improve $D$. salina cultivation for $\beta$-carotene production and other biotechnological and industrial applications.
\end{abstract}

Keywords: $\beta$-carotene, Dunaliella salina, eucalyptus, elderberry, leaf extracts, metabolites, stress

\section{Introduction}

Natural products or bioactive chemical compounds such as leaf extracts, are water soluble or insoluble substances that are produced in the main metabolic pathway or secondary metabolic processes of plants (Swain 1977), and can have advantageous or injurious effects on the target organism. These biomolecules are produced in many plant organs, including leaves, flowers, fruits, and buds (Putnam \& Tang 1986). Many bioactive chemicals, even at low concentrations, are toxic to higher plants and they can affect many physiological processes including seed germination and the growth of plants (Weston et al. 2002; Azania et al. 2003; Weston \& Duke 2003). In contrast, it has been proposed that the biologically active compounds act as metabolic triggers or enhancers and can be applied in various marine and freshwater microalgae to enhance biomass production and synthesis of valuable metabolites such as pigments, vitamins, or lipids (Mendes \& Vermelho 2013; Yu et al. 2015). Thus, bioactive chemical substances can be considered as a practical approach and a promising strategy to enhance bioaccumulation of high-value products

\footnotetext{
${ }^{1}$ Department of Biology, Faculty of Science, University of Sistan and Baluchestan, Zahedan, 98167-45639, Iran

${ }^{2}$ Department of Chemistry, Faculty of Science, University of Sistan and Baluchestan, Zahedan, 98167-45639, Iran

* Corresponding author: aeinali@science.usb.ac.ir
} 
Metabolic responses and $\beta$-carotene production by the

unicellular green alga Dunaliella salina exposed to leaf extracts

in freshwater and marine microalgae (Mendes \& Vermelho 2013; Yu et al. 2015).

Eucalyptus species are widely established throughout the world because of their rapid growth, wide adaptability, and high productivity (Singh \& Toky 1995; Gardner 2007). The phytotoxicity effects of eucalyptus on growth of plants have been extensively reported in the literature (Sasikumar et al. 2002; Bajwa \& Nazi 2005; El-Khawas \& Shehata 2005). Phenolics released from the eucalyptus leaf residue and roots have phytotoxicity effects on other plant species (Sasikumar et al. 2002; Florentine \& Fox 2003). In addition to eucalyptus, the phytotoxicity effects of other plants e.g. elderberry (Sambucus ebulus) have also been reported (Christina et al. 2015). It has recently been demonstrated that $S$. ebulus restrict the colonization and subsequent development of Fallopia $x$ bohemica (Christina et al. 2015). Phytochemical analysis on aqueous extracts of eucalyptus and elderberry leaves demonstrate the high relatively amounts of phenolic compounds and antioxidant potential in these plants (see Results section). Thus, these bioactive substances might be effective to improve valuable metabolites biosynthesis in microalgae.

Dunaliella, a marine unicellular green alga, is a halotolerant organism that has adapted to survive in different environmental conditions (Rothschild \& Mancinelli 2001). It has frequently been considered as a model system in stress physiology because of its high tolerance and physiological plasticity under unstable conditions (Avron \& Ben-Amotz 1992; Cowan et al. 1992). Most Dunaliella species are able to accumulate large amounts of $\beta$-carotene both naturally and under different stress conditions (BenAmotz \& Avron 1983; Cowan et al. 1992; Salguero et al. 2003). Dunaliella salina is the best known commercial source of natural $\beta$-carotene among all organisms in the world (Borowitzka 1995). This alga was shown to accumulate $\beta$-carotene to more than $10 \%$ of its dry weight when grown under growth-limiting conditions such as high irradiance, high salinity, high temperature, and limiting nutrients (Ben-Amotz et al. 1982; Ben-Amotz \& Avron 1983; Cowan et al. 1992; Salguero et al. 2003; Raja et al. 2007; Einali $\&$ Valizadeh 2015). $\beta$-carotene accumulates as droplets in intrachloroplastic lipoidal globules and plays a role in protecting chlorophyll against photo-damage (Ben-Amotz \& Avron 1983; Ben-Amotz et al. 1988). $\beta$-carotene extracted from Dunaliella is also a precursor of vitamin A and widely used as antioxidant in the food, pharmaceutical, and cosmetic industries (Dufosse et al. 2005; Murthy et al. 2005). Hence, Dunaliella is biotechnologically regarded as a very important microalga and it is cultivated for natural production of $\beta$-carotene (Spolaore et al. 2006; Campo et al. 2007). It has been demonstrated that the use of bioactive compounds induce the accumulation of valuable bioproducts in various marine and freshwater microalgae (Mendes \& Vermelho 2013; Yu et al. 2015). Thus, it can be hypothesized that the use of leaf extracts may improve $\beta$-carotene productivity in Dunaliella cultivations. Our preliminary experiments revealed that aqueous extracts of eucalyptus and elderberry leaves display significant effects on Dunaliella physiology. Thus, these two plants were selected to examine microalgae response to the bioactive substances. This research aimed to assess the influence of leaf aqueous extracts of eucalyptus and elderberry on growth and $\beta$-carotene production in D. salina and to study the alga tolerance to leaf extracts.

\section{Materials and methods}

\section{Plant material and preparation of extracts}

Leaves of eucalyptus (Eucalyptus globulus Labill.) and elderberry (Sambucus ebulus L.) were harvested in late May 2014 from the Botanic Garden of the University of Sistan and Baluchestan. Tissues were air-dried, and then ground by a blender to obtain a fine powder. A $10 \%(\mathrm{w} / \mathrm{v})$ aqueous extract was prepared as described by Bogatek et al. (2006). Briefly, $10 \mathrm{~g}$ of powder was extracted with $100 \mathrm{ml}$ of distilled water for $24 \mathrm{~h}$ at room temperature. The extracts were filtered through four layers of cheesecloth to remove the debris, and re-filtered through Whatman No.1 filter paper. The resultant aqueous filtrate was used as the $10 \%(\mathrm{w} / \mathrm{v})$ stock of aqueous extracts according to Bogatek et al. (2006).

\section{Evaluation of phenolic and flavonoid content}

The content of phenolics in the aqueous extracts was determined using Folin-Ciocalteu reagent (FCR) by the method of Singleton et al. (1999) with some modifications. Briefly, $0.5 \mathrm{ml}$ of plant extract was mixed with $2.5 \mathrm{ml}$ of $10 \%$ FCR. After $5 \mathrm{~min}$ at room temperature, $2 \mathrm{ml}$ of $5 \% \mathrm{Na}_{2} \mathrm{CO}_{3}$ was added to mixture. The mixture was left for $30 \mathrm{~min}$ at room temperature in darkness. The absorbance was measured at $765 \mathrm{~nm}$ by a DR 5000 UV-VIS spectrophotometer (Hach, USA) and the phenolic content was calculated using known concentrations of catechol as the standard.

Total flavonoid content of the extracts was estimated by the aluminium chloride colorimetric method using quercetin as a standard (Chang et al. 2002). Briefly, $0.5 \mathrm{ml}$ of each extract was mixed with $1.5 \mathrm{ml}$ of $95 \%$ ethanol, $0.1 \mathrm{ml}$ of $10 \%$ aluminium chloride, $0.1 \mathrm{ml}$ of $1 \mathrm{M}$ sodium acetate, and $2.8 \mathrm{ml}$ of distilled water. The mixture was incubated at room temperature for $30 \mathrm{~min}$ and the absorbance was measured at $415 \mathrm{~nm}$.

\section{Determination of antioxidant activity of the extracts}

The radical scavenging capacity of the aqueous extracts was evaluated using 1, 1-diphenyl-2-picrylhydrazyl (DPPH) and ferric reducing antioxidant potential (FRAP) methods.

The DPPH radical scavenging activity of the extracts 
was determined as described by Bao et al. (2005) with some modifications. An aliquot $(0.1 \mathrm{ml})$ of diluted extracts was added to $3 \mathrm{ml}$ of $0.1 \mathrm{mM}$ DPPH solution, and then left for $30 \mathrm{~min}$ in the dark at room temperature. The change in absorbance was measured at $517 \mathrm{~nm}$. The control sample (extract-free mixture) comprised $0.1 \mathrm{ml}$ of methanol and $3 \mathrm{ml}$ of DPPH solution. A standard curve was constructed as a function of ascorbic acid concentration. The radical scavenging activity of the extracts was expressed as $\mathrm{mg}$ ascorbic acid equivalent antioxidant capacity (AEAC) per gram dry weight.

The ferric-reducing capacity of the extracts was measured according to the method of Benzie \& Strain (1996) with some changes. The reaction mixture in a final volume of 2 $\mathrm{ml}$ consisted of FRAP reagent and $0.2 \mathrm{ml}$ of diluted extracts. FRAP reagent consisted of acetate buffer ( $\mathrm{pH} 3.6), 10 \mathrm{mM}$ 2, 4, 6-tripyridyl-S- triazine (TPTZ) solution in $40 \mathrm{mM}$ $\mathrm{HCl}$, and $20 \mathrm{mM}$ ferric chloride at a ratio10:1:1 (v/v/v). The reaction mixture was incubated for $10 \mathrm{~min}$ in a water bath at $37^{\circ} \mathrm{C}$. The absorbance of samples was recorded at 595 $\mathrm{nm}$. The ferric-reducing power of the extracts was expressed as mg AEAC per gram dry mass of tissue.

\section{Algal culture and experimental design}

Dunaliella salina Teod. UTEX 200 was obtained from the Culture Collection of Algae at the University of Texas at Austin (UTEX). The cells were grown in modified Johnson's culture medium at $\mathrm{pH}=7.5$ (Einali \& Valizadeh 2015), containing concentration of $1.5 \mathrm{M} \mathrm{NaCl}$. Cultures were incubated in a culture room at $25{ }^{\circ} \mathrm{C}$ with continuous shaking at $100 \mathrm{rpm}$ (Unimax 2010, Heidolph, Germany) under a $16 \mathrm{~h}$ light $/ 8 \mathrm{~h}$ dark regime and an irradiance of 70 $\mu \mathrm{mol}$ photons $\mathrm{m}^{-2} \mathrm{~s}^{-1}$. During the logarithmic growth phase, the cell suspensions were transferred into aseptic flasks containing concentrations of $0,1,2,3$, and $4 \%$ of the leaf aqueous extracts in final volume of $150 \mathrm{ml}$. Cultures in the absence of the leaf extracts served as control. To exclude bacteria and other contaminants, the aqueous extracts were filtered through a double $0.2 \mu \mathrm{m}$ filter unit into a sterile bottle before use. Cells treated with leaf extracts were incubated under the same conditions as used during growth period. Three different flasks were prepared for each experiment and sampled at time zero and $48 \mathrm{~h}$ after phytotoxins treatment. Following this period, the algal cells were harvested by centrifuging at 2,000 $\times g$ for $10 \mathrm{~min}$ (Universal 320, Hettich, Germany) and resuspended in fresh iso-osmotic and iso-volumetric medium to recover the cells from leaf extracts, and the cell growth was then re-monitored.

\section{Determination of cell growth and fresh weight}

Dunaliell salina cells were enumerated using a haemocytometer under a light microscope (CX21FS1, Olympus, Japan) (Schoen 1988; Andersen 2005). To measure fresh weight, $30 \mathrm{ml}$ of cell suspension was centrifuged at $2,000 \times g$ for $10 \mathrm{~min}$. The pellet was resuspended in a small volume of supernatant (used medium) and transferred to a pre-weighed micro-tube and recentrifuged at $10,000 \times g$ for 5 $\mathrm{min}$. The resultant pellet was washed with $0.2 \mathrm{M} \mathrm{NaCl}$ fresh culture medium to remove residual salt and then weighed (Haghjou et al. 2014).

\section{Pigment determination}

Pigments including Chlorophylls (Chl) and $\beta$-carotene were extracted from algal pellets obtained by centrifuging 1 $\mathrm{ml}$ of cell suspension (10,000 $\times \mathrm{g}$ for $5 \mathrm{~min}$ ) with $1 \mathrm{ml}$ of $80 \%$ $(\mathrm{v} / \mathrm{v})$ acetone for $5 \mathrm{~min}$. The mixture was recentrifuged at $10,000 \times g$ for $2 \mathrm{~min}$ and the resultant supernatant used to quantify pigments. Chl content was measured spectrophotometrically according to method of Arnon (1949). $\beta$-carotene concentration was calculated using $\mathrm{E}_{1 \mathrm{~cm}}^{1 \%}$ of 2,273 at $480 \mathrm{~nm}$ (Ben-Amotz \& Avron 1983).

\section{Total soluble sugar and protein determination}

For total soluble sugar determination, weighed pellets (obtained from $30 \mathrm{ml}$ of cell suspension as described above) were extracted with $5 \mathrm{ml}$ of $80 \%(\mathrm{v} / \mathrm{v})$ ethanol at $70^{\circ} \mathrm{C}$ for $10 \mathrm{~min}$. The supernatant was saved and the extraction was repeated four times with $80 \%$ ethanol. These extracts were combined and concentrated to one sixth of their original volume by evaporation. About $10 \mathrm{mg}$ of charcoal was added to the concentrated extract $(4 \mathrm{ml})$ and then centrifuged at $12,000 \times g$ for $10 \mathrm{~min}$ to remove the pigments. Total soluble sugar concentration in the resultant clear supernatant was quantified by the anthrone method of McCready et al. (1950).

For total soluble protein determination, weighed pellets (obtained from $30 \mathrm{ml}$ of cell suspension as described above) were suspended in an extraction buffer containing 100 $\mathrm{mM}$ cold potassium phosphate buffer $(\mathrm{pH} 7.0), 1 \mathrm{mM}$ EDTA, $10 \mathrm{mM} \mathrm{KCl}, 1 \mathrm{mM} \mathrm{MgCl}$, $10 \%$ glycerol, $1 \%$ (w/v) Polyvinylpolypyrrolidone and $50 \mathrm{mM} \beta$-mercaptoethanol. The suspension was sonicated twice for $30 \mathrm{~s}$ with $2 \mathrm{~min}$ interval. To remove pigments, $10 \mathrm{mg}$ charcoal was added to the homogenate and then centrifuged $(12,000 \times g$ for $10 \mathrm{~min}$ at $4^{\circ} \mathrm{C}$ ) (Einali \& Valizadeh 2015). The resultant supernatant was used to estimate total soluble proteins using bovine serum albumin (BSA) as the standard (Bradford 1976).

\section{Statistical analysis}

All data were expressed as the average and standard deviation (SD) of three separate experiments from independent flasks. Analysis of variance (ANOVA) was taken 
Metabolic responses and $\beta$-carotene production by the

unicellular green alga Dunaliella salina exposed to leaf extracts

to determine significant differences between treatments at $P<0.05$ with a Duncan multiple comparisons of means test.

\section{Results and discussion}

\section{Phenolic content and antioxidant activity of the leaf extracts}

Phenolic content of eucalyptus and elderberry extracts was estimated by $20.8 \mathrm{mg} \mathrm{g}^{-1} \mathrm{DW}$ and $15.07 \mathrm{mg} \mathrm{g}^{-1} \mathrm{DW}$, respectively. Values of flavonoids were determined $27.64 \mathrm{mg}$ $\mathrm{g}^{-1} \mathrm{DW}$ for eucalyptus and $19.75 \mathrm{mg} \mathrm{g}^{-1} \mathrm{DW}$ for elderberry (Tab. 1). Eucalyptus extracts showed a relatively high reducing power (73.23 mg AEAC g $\left.{ }^{-1} \mathrm{DW}\right)$ and $\mathrm{DPPH}$-scavenging capacity (108.52 $\left.\mathrm{mg} \mathrm{AEAC}^{-1} \mathrm{DW}\right)$ than elderberry extracts (21.59 $\mathrm{mg} \mathrm{AEAC}^{-1} \mathrm{DW} ; 100.85 \mathrm{mg} \mathrm{AEAC} \mathrm{g}^{-1} \mathrm{DW}$ ). However, no significant change was observed in DPPH-scavenging capacity between two extracts (Tab. 1). Plant phenolics mainly are phenolic acids and flavonoids. Phenolics have one or more aromatic rings with one or more hydroxyl groups. The antioxidant capacity of the phenolics principally depends on the number and position of the hydroxyl group (Rice-Evans et al. 1995). Therefore, high phenolics content is correlated with further antioxidant capacity (Rice-Evans et al. 1995; Fresco et al. 2006).

\section{Bioassay results}

The mean values for cell number in D. salina suspensions incubated with different concentrations of leaf extracts at time zero and after $48 \mathrm{~h}$, together with fresh weight, pigment content, total sugar and protein concentrations, expressed on a per cell basis, are shown in the Tables S1 and $S 2$ in supplementary material. All data were expressed as the percentage change between the initial values at time zero and $48 \mathrm{~h}$ of leaf extracts treatment.

\section{Effects of leaf extracts on cell growth kinetics and} fresh weight

Figure 1 (A, B) shows the growth pattern of D. salina incubated with various concentrations of eucalyptus and elderberry extracts, while figure $1(C, D)$ displays the recovered algal cells from these extracts during a period of $96 \mathrm{~h}$. Extracts of both species at all concentrations used led to the inhibition of alga growth. Comparison of changes in cell number between 0 and $48 \mathrm{~h}$ of leaf extracts treatment also show a significant decrease in cell density in all cultures incubated with leaf extracts (Fig. 2A). However, elderberry concentration of $1 \%$ decreased the cell number much less than eucalyptus (Fig. 2A). The severe decrease in cell number can be attributed to the growth inhibited by extracts. Regarding to the higher amounts of phenolics and flavonoids in eucalyptus extracts (Tab. 1), it can be expected that the extracts have more growth inhibitory activity than elderberry extracts. Thus, more growth inhibition occurred in $1 \%$ concentration of eucalyptus than elderberry. Collecting algal cells after $48 \mathrm{~h}$ and resuspending them in fresh medium resulted gradually in the re-growth due to the removal of leaf extracts. However, growth rate in the cells recovered from extracts of both species was lower than control (Fig. 1C, D). Percentage changes in cell number between time zero and $48 \mathrm{~h}$ of recovery period showed a more growth rate in suspensions recovered from elderberry than eucalyptus extracts (Fig. 2B).

No difference in the fresh weight of cells was observed between time zero and $48 \mathrm{~h}$ in leaf extracts-free cultures (control) (Fig. 2C). However, the fresh weight of cells exposed to leaf extracts was significantly higher than control, and increased concomitantly with leaf extracts concentration. Algal cells incubated with eucalyptus extracts had pronouncedly higher fresh weight than those incubated with elderberry extracts (Fig. 2C). Such increase in fresh weight along with a decrease in cell number was also observed in menadione-treated D. viridis cells (Haghjou et al. 2014). Increase in fresh weight caused by starch accumulation was reported in $D$. tertiolecta illuminated with a combination of photosynthetically active radiation, UVA and UVB despite the lower cell growth (García-Gomez et al. 2012). Leaf extracts-induced fresh weight increase can indicate that the remaining alive cells develop an extensive resistance to growth inhibitors. Massive accumulation of measured metabolites in this study including $\beta$-carotene, Chl, total sugars, and protein content may contribute to increased fresh weight induced by leaf extracts. In addition to starch (Tian \& Yu 2009; García-Gomez et al. 2012), accumulation of lipids (Yilancioglu et al. 2014) induced by oxidative stress in Dunaliella sp. may also be involved. In contrast, recovering cells from the leaf extracts represented that the changes of

Table 1. Phenol and Flavonoids content and antioxidant activity of eucalyptus and elderberry extracts. The values are the mean \pm $\mathrm{SD}$ of three separate experiments. Different letters in same column represent significant differences between the two extracts at $\mathrm{P}<$ 0.05 according to the Duncan test

\begin{tabular}{|c|c|c|c|c|}
\hline Cultivars & $\begin{array}{c}\text { Phenol } \\
\text { [mg g-DW] }\end{array}$ & $\begin{array}{l}\text { Flavonoids } \\
\left.\text { (mg g } \text { g }^{-1} \mathrm{DW}\right]\end{array}$ & $\begin{array}{l}\text { DPPH method } \\
\text { [mg AEAC } \mathrm{g}^{-1 D W]}\end{array}$ & $\begin{array}{l}\text { FRAP method } \\
{\left[m g \text { AEAC } g^{-1} D W\right]}\end{array}$ \\
\hline eucalyptus & $20.80 \pm 1.29^{b}$ & $27.64 \pm 1.06^{b}$ & $108.52 \pm 2.50^{a}$ & $73.23 \pm 1.07^{b}$ \\
\hline elderberry & $15.07 \pm 0.86^{\mathrm{a}}$ & $19.75 \pm 0.62^{\mathrm{a}}$ & $100.85 \pm 2.30^{\mathrm{a}}$ & $21.59 \pm 0.97^{\mathrm{a}}$ \\
\hline
\end{tabular}



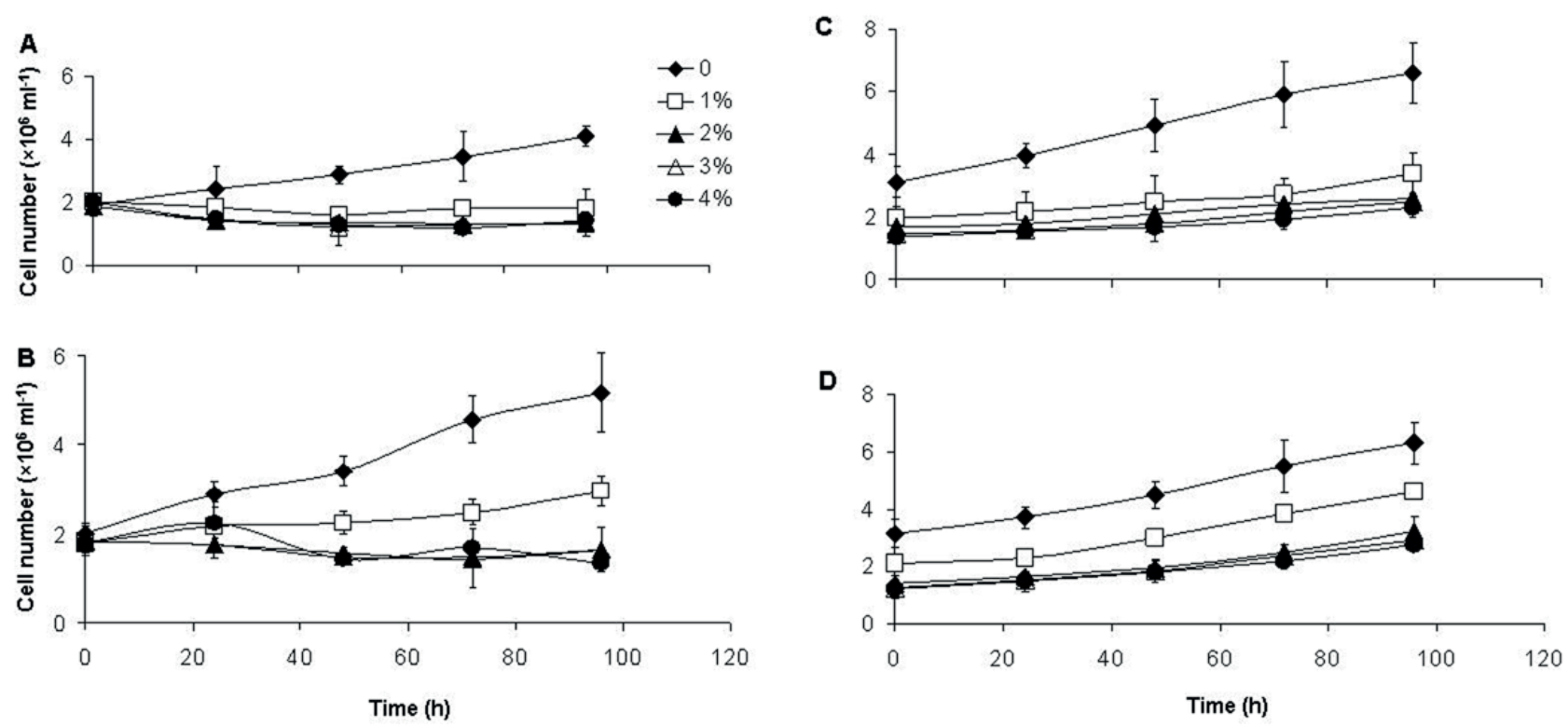

Figure 1. Growth pattern of Dunaliella salina during a period of $96 \mathrm{~h}$. (A, B) Growth of cells incubated with concentrations of 0, 1, 2, 3 , and $4 \%$ aqueous extracts of eucalyptus (A) and elderberry (B) leaves. (C, D) Growth pattern of the cells recovered from the cultures incubated with the abovementioned concentrations of aqueous extracts of eucalyptus (C) and elderberry (D) leaves after $48 \mathrm{~h}$. Each value is the mean $\pm S D$ of three separate measurements from independent flasks.
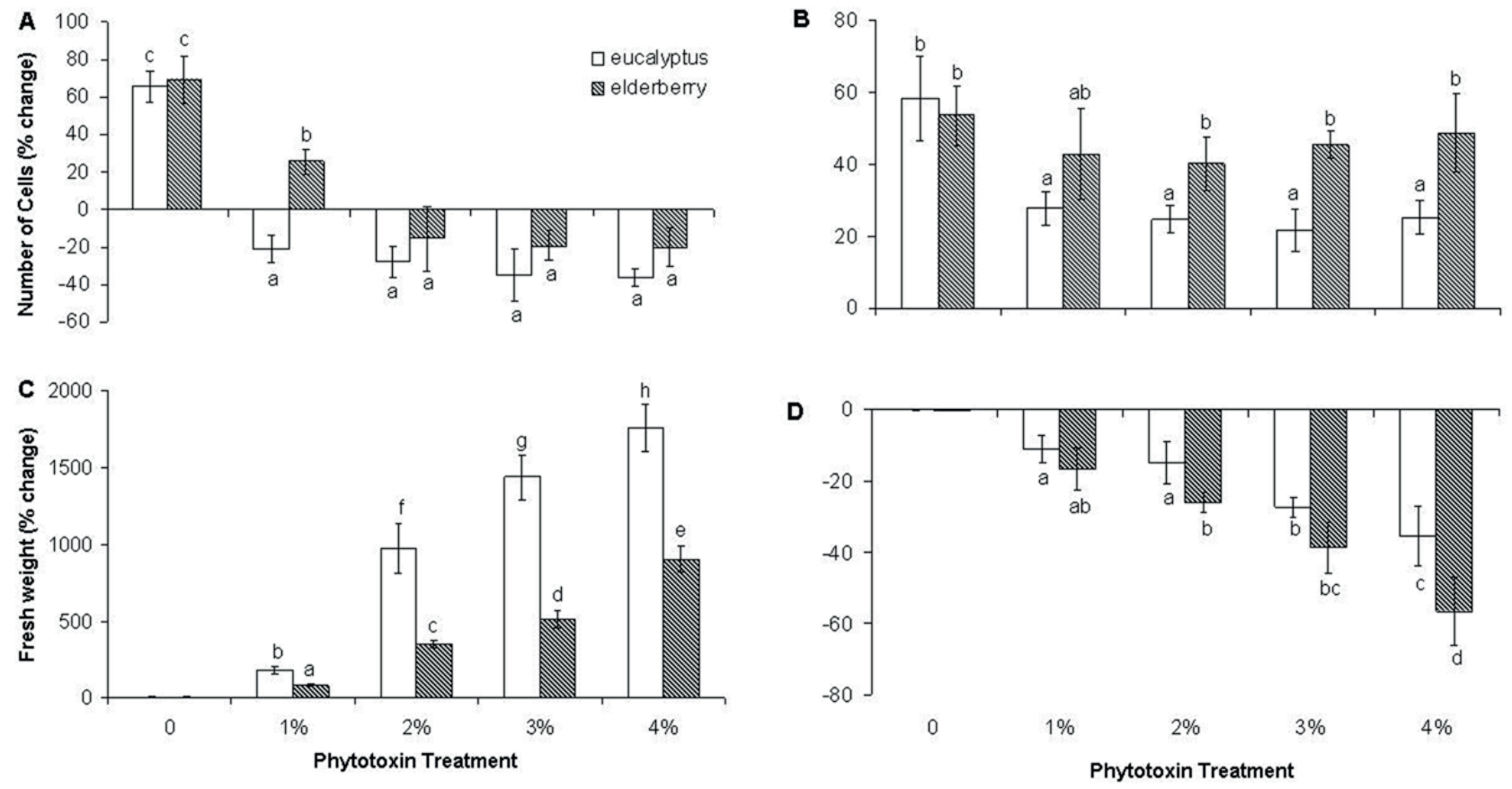

Figure 2. (A, C) Changes in number (A) and fresh weight (C) of Dunaliella salina cells treated with different concentrations of eucalyptus and elderberry extracts. (B, D) Changes in number (B) and fresh weight (D) of Dunaliella salina cells recovered from the cultures treated with different concentrations of eucalyptus and elderberry extracts after $48 \mathrm{~h}$. The data are expressed as percentage change between 0 and $48 \mathrm{~h}$ of leaf extracts treatment or recovery period. Each value is the mean \pm SD of three independent experiments from independent flasks. Different letters indicate significant differences between the various treatments at $\mathrm{P}<0.05$ according to the Duncan test. 
fresh weight of cells between time zero and $48 \mathrm{~h}$ of recovery period was significantly decreased as compared to control (Fig. 2D). This may be the result of alleviation of growth inhibitory activity induced by leaf extracts.

\section{Effects of leaf extracts on chlorophylls and $\beta$-carotene}

A pronounced increase in $\mathrm{Chl}$ a concentration, compared with extract-free cultures (control), occurred after $48 \mathrm{~h}$ of incubation with 1 and $2 \%$ concentrations of eucalyptus and also 1,2 and $3 \%$ concentrations of elderberry (Fig. $3 \mathrm{~A})$. However, the maximum percentage change for $\mathrm{Chl}$ a content was observed in eucalyptus concentration of 1 $\%$ and also elderberry concentration of $2 \%$ (Fig. 3A). A significant decrease in $\mathrm{Chl} a$ concentration was detectable in cells incubated with $4 \%$ elderberry (Fig. 3A). Chl $b$ concentration was significantly stimulated in cultures treated with $1 \%$ eucalyptus and $2 \%$ elderberry extracts (Fig. 3B). The $\mathrm{Chl} b$ content was increased to $224 \%$ and 153 $\%$ in $1 \%$ eucalyptus and $2 \%$ elderberry concentrations, respectively (Fig. 3B). Chl $b$ concentration was drastically decreased in cells treated with $4 \%$ eucalyptus (Fig. 3B). The pronounced increase in $\mathrm{Chl} b$ concentration against $\mathrm{Chl} a$ (Fig. 3A, B) may be indicative the fact that the $\mathrm{Chl}$ $b$ production is required to accumulate the practical light- harvesting complexes in the chloroplasts of green algae and higher plants (Eggink et al. 2001; 2004; Biswal et al. 2012). In addition, increase of $\mathrm{Chl} b$ biosynthesis can regulate the expression of some special thylakoid membrane proteins, which raise the antenna complex size and likewise, the electron transport rates (Tanaka et al. 2001; Biswal et al. 2012). Such massive increase in $\mathrm{Chl} b$ content has also been observed in some studies including our pervious report on $D$. salina treated with propyl gallate, a synthetic antioxidant (Einali \& Valizadeh 2015), and another study on $D$. salina grown over a salinity gradient (Mishra et al. 2008). Total Chl concentration was pronouncedly increased as observed for Chl a content (Fig. 3C). A significant increase in total $\mathrm{Chl}$ concentration occurred in $1,2 \%$ eucalyptusincubated cells or 1, 2, and $3 \%$ concentrations of elderberry, and a clear decline was obtained in the cells incubated with $4 \%$ extracts of both species (Fig. 3C). The decrease is because of a substantial decrease in either $\mathrm{Chl} b$ or $\mathrm{Chl}$ a concentration observed in the cultures treated with $4 \%$ eucalyptus or elderberry, respectively (Fig. 3A, B). Despite cell mortality in extracts-treated cultures, increase in $\mathrm{Chl}$ concentration can be interpreted as the necessity of the cells to compensate of reduced photosynthetic and metabolic activities when cells are subjected to mortal concentrations of the extracts. In fact, the surviving cells are capable to tolerate and raise resistance to the unstable conditions. Such significant increase in $\mathrm{Chl}$ content has also been reported
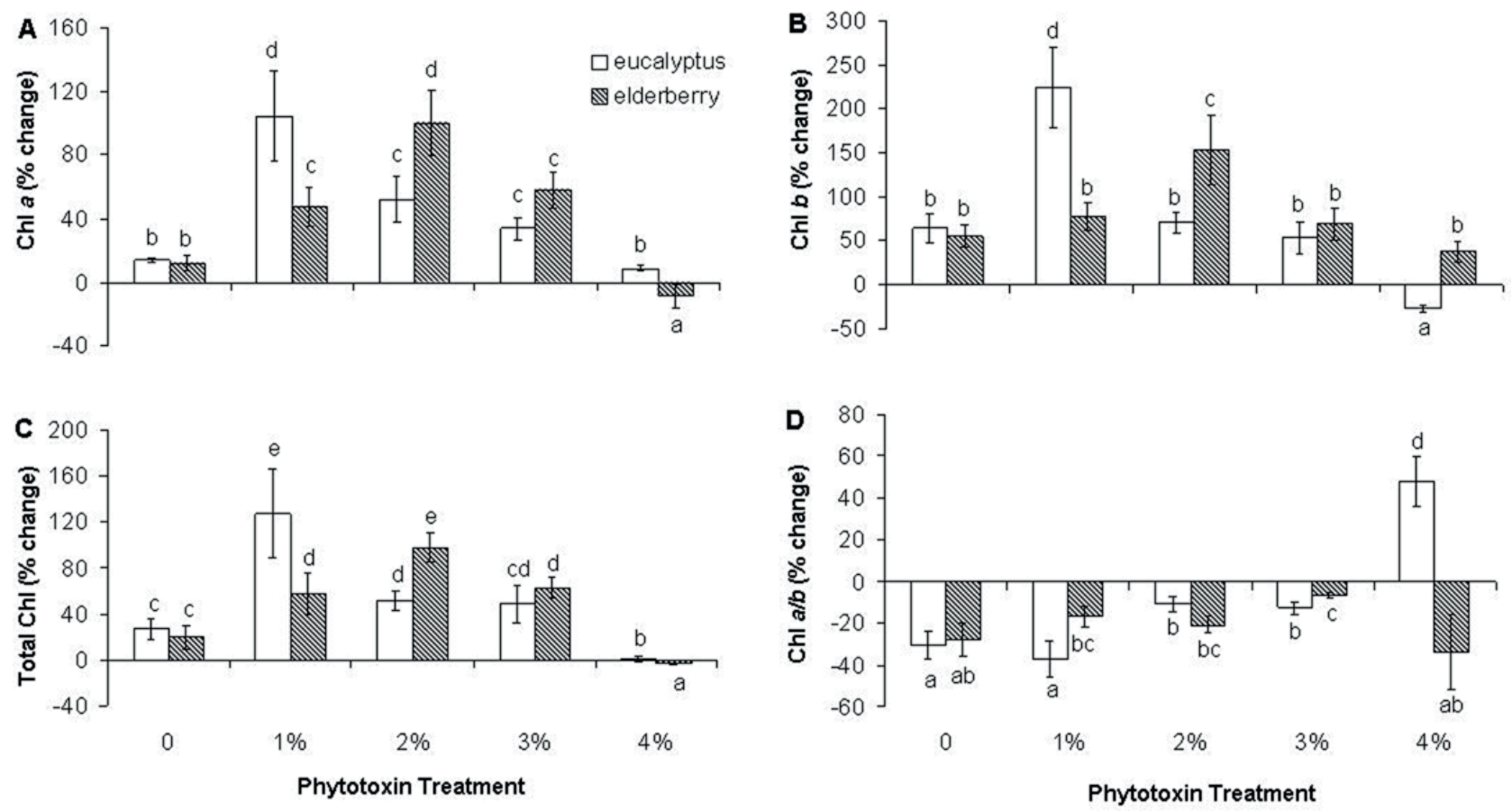

Figure 3. Changes in photosynthetic pigments of Dunaliella salina cells incubated with different concentrations of eucalyptus and elderberry leaf extracts. The data are expressed as percentage change between 0 and $48 \mathrm{~h}$ of leaf extracts treatment. (A) Chl $a$, (B) $\mathrm{Chl}$ $b$, (C) Total Chl, (D) Chl a/b ratio. Each column represents the mean \pm SD of triplicate independent measurements from independent flasks. Different letters indicate significant differences between the various treatments at $\mathrm{P}<0.05$ according to the Duncan test. 
in green sectors of variegated leaves from the immutans (Baerr et al. 2005; Rosso et al. 2006) and ghost (Shahbazi et al. 2007) mutants. A reduction in $\mathrm{Chl} a / b$ ratio after 48 $\mathrm{h}$ of treatment was detectable in both control and nearly all extracts treatments (Fig. 3D). It indicates the fact that $\mathrm{Chl} b$ is synthesized at a higher rate than $\mathrm{Chl} a$. In fact, it is because of the fact that $\mathrm{Chl} b$ synthesis proceed from $\mathrm{Chl} a$ by conversion of methyl group on the $\mathrm{B}$ ring of $\mathrm{Chl}$ a molecule to a formyl group (Porra et al. 1994). However, the $\mathrm{Chl} a / b$ ratio was increased concurrently with concentrations more than $1 \%$ eucalyptus and reached $48 \%$ in cultures treated with $4 \%$ eucalyptus (Fig. 3D). The increase can be attributed to a severe reduction in $\mathrm{Chl} b$ content (Fig. 3B). However, a significant increase in this ratio was also appreciable in cells exposed to $3 \%$ elderberry (Fig. 3D), because of a pronounced increase in $\mathrm{Chl} a$, rather than decrease in $\mathrm{Chl}$ $b$ content (Fig. 3A, B).

$\beta$-carotene concentration was significantly increased after $48 \mathrm{~h}$ of treatment in cultures incubated with concentrations of 1,2 , and $3 \%$ extracts of both species (Fig. 4). As Chl $a$, the greatest percentage change for $\beta$-carotene concentration occurred in $1 \%$ eucalyptus and $2 \%$ elderberry-exposed cells (Fig. 4). Likewise, a pronounced decrease in $\beta$-carotene concentration was detectable in $4 \%$ elderberry-incubated cells in comparison with control (Fig. 4). $\beta$-carotene is considered as an important non-enzymatic antioxidant that quench singlet oxygen and triplet $\mathrm{Chl}$, protect chlorophylls (Ben-Amotz et al. 1989) and inhibit lipid peroxidation of photosynthetic membranes (Demmig-Adams et al. 1996; Li et al. 2012). It has been proposed that $\beta$-carotene also act as a carbon sink to accumulate the excess carbon produced during photosynthesis under stress conditions (Borowitzka \& Borowitzka 1988). It is known that Dunaliella accumulate large amount of $\beta$-carotene while cell division is retard. Thus, adverse environmental conditions, such as high salinity, low temperature, high irradiance, or nutrient deficiency increase the accumulation of $\beta$-carotene in this alga (BenAmotz et al. 1982; Ben-Amotz \& Avron 1983; Ben-Amotz 1996; Einali \& Shariati 2012; 2015; Einali \& Valizadeh 2015). Due to that, Dunaliella has been widely considered as an interesting model for studying $\beta$-carotene biosynthesis. Previous studies have stated that increase in $\beta$-carotene content in Dunaliella is associated with Chl decrease, so that the $\beta$-carotene-to- $C h l$ ratio increases in inverse relation to growth rate under unstable environmental conditions (Ben-Amotz et al. 1982; Ben-Amotz \& Avron 1983). In contrast, our results represent that increase of $\beta$-carotene concentration is coupled with an increase in Chl content. Therefore, no statistically significant change was observed in $\beta$-carotene-to-Chl ratio (data not shown). However, declined growth rate does not indicate a complete mortality of cell because leaf extracts-incubated Dunaliella cells survive and accumulate high levels of $\mathrm{Chl}$ (Fig. 3). Thus, it is probably that the leaf extracts-induced $\beta$-carotene concentration increase could be brought about maintenance of $\mathrm{Chl}$, in addition to its biosynthesis stimulation under leaf extracts-induced stress. It is in agreement with our previous results on propyl gallateinduced $\beta$-carotene under salt stress (Einali \& Shariati 2012; 2015; Einali \& Valizadeh 2015). Based on the results, the highest concentrations of both $\mathrm{Chl}$ and $\beta$-carotene were observed in cells exposed to $1 \%$ eucalyptus and $2 \%$ elderberry (Figs. 3, 4). Because phenolics concentration and antioxidant activity of eucalyptus leaf extracts is higher than elderberry, the highest pigments concentration in eucalyptus-incubated cultures occurred in concentrations less than elderberry leaf extracts. Higher concentrations lead to decrease in pigment content because of increased inhibitory effects of leaf extracts. However, $\beta$-carotene

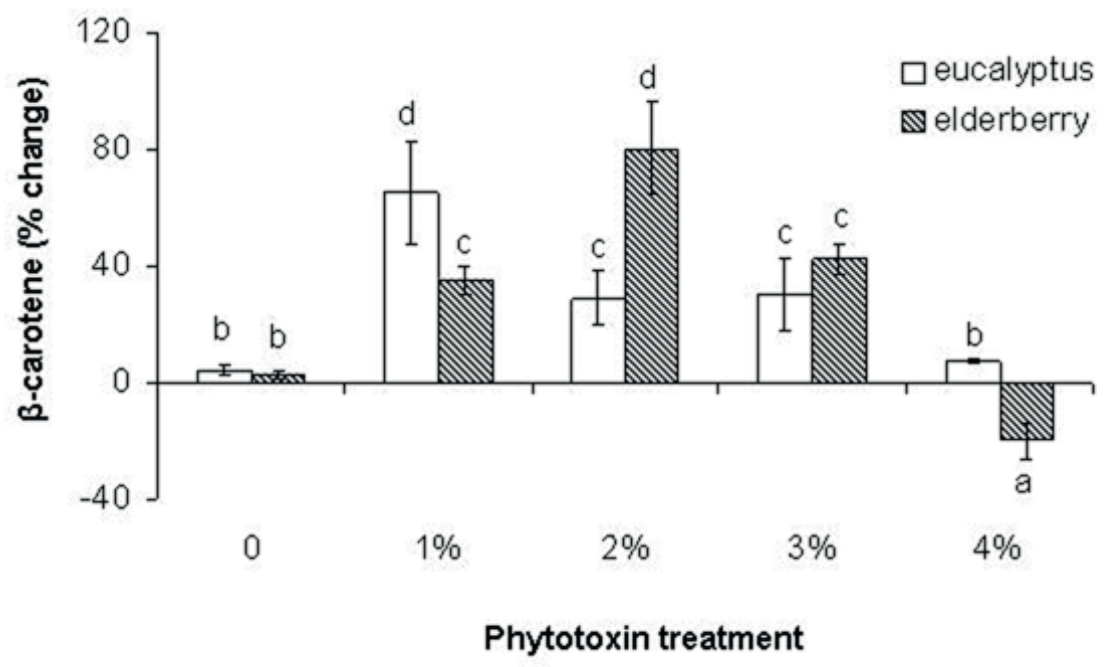

Figure 4. Changes in $\beta$-carotene concentration of Dunaliella salina cells in response to various concentrations of extracts of eucalyptus and elderberry leaves. The values are presented as percentage change between 0 and $48 \mathrm{~h}$ of leaf extracts treatment. Bars show the mean \pm SD of three separate measurements from independent flasks. Different letters indicate significant differences between the various treatments at $\mathrm{P}<0.05$ according to the Duncan test. 
concentration decreased or remained unchanged in cells incubated with $4 \%$ leaf extracts (Fig. 4), while reduced cell number in cultures treated with different doses of extracts was statistically unchanged relative to each other (Fig. 2A). Therefore, it seems that other metabolic adjustments rather than $\beta$-carotene biosynthesis probably is involved in algae tolerance to high doses of leaf extracts.

\section{Effects of leaf extracts on total sugar content}

Total sugar content was significantly increased following exposure of cells to different doses of leaf extracts. However, in doses more than $2 \%$ eucalyptus, the values of sugar remained roughly unchanged (Fig. 5A). It has been demonstrated that different solutes accumulate in response to various stress conditions including leaf extracts (Prado et al. 2000; Gill et al. 2001; Duran-Serantes et al. 2002; Mishra et al. 2008; Mishra \& Jha 2011). The osmolytes can act as osmoprotectants during osmotic stress without interfere with normal biochemical reactions (Duran-Serantes et al. 2002). Sugars have a key role in maintaining the osmotic regulation of cells during stress conditions (Mishra et al. 2008; Mishra \& Jha 2011). Because of having different phenolic substances, leaf extracts can induce osmotic stress through decrease of osmotic potential in plant growth medium (Kupidlowska et al. 2006). Stress induction by leaf extracts has also been reported previously (Romero-Romero et al. 2002). Dunaliella cells accumulate high levels of sugar content in response to a salinity gradient (Mishra et al. 2008). Since increase in salt concentration is associated with a decrease in osmotic potential (Golldack et al. 1995), sugar content accumulation against increasing salinity seems reasonable. However, the metabolites accumulation and cell mortality in hyper salinity (Mishra et al. 2008; Einali $\&$ Valizadeh 2015) is lower than allelopathy stress (present results). It can be due to the inhibitory effects of extracts. It is consistent with a study showing that the impact of sunflower leaf extracts on germinating mustard seeds is mostly by their toxicity and partly by their contribution to osmotic potential (Kupidlowska et al. 2006). Given to the evidence, leaf extracts-stimulated metabolites production can be related to inhibitory effects of extracts rather than osmotic pressure. However, as suggested before (Hanson 1980; Singh \& Singh 1993), the accumulation of osmolytes is a response to plant stress and does not indicate an adaptation to unstable environment, which confirm the fact that Dunaliella cells tolerate inhibitory activity of leaf extracts.

\section{Effects of foliar extracts on protein concentration}

The percentage change in protein concentration between 0 and $48 \mathrm{~h}$ of leaf extracts treatment displayed an enhancing profile concomitantly with extracts concentration in a similar pattern to sugar content (Fig. 5B). It is stated that plant stress can induce protein degradation or lowering protein synthesis, because of senescence acceleration (Duran-Serantes et al. 2002). The reduction of total protein in Abutilon theophrasti induced by $p$-hydroxybenzoic acid, a phenolic derivative of benzoic acid, can be resulted from heightened protein degradation or prevention in protein synthesis (Mersie \& Singh 1993). However, in contrast to the studies, we found high accumulation of proteins in leaf extracts-incubated cells. Unfavourable conditions induce the expression of proteins known as stress proteins, which is believed to involve in protecting cells. The stress proteins may be induced in response to allelochemical stress, as induced by salinity and dehydration (Vierling 1991; Bray 1993). Stress and molecular signals inside the cell cause the activation of alternative biochemical pathways, protein expression changes, and inhibition of others that are typical of the stable conditions (Bohnert \& Sheveleva 1998). In consistency with our results, high salinity-grown Dunaliella cells showed an increase nearly $100 \%$ in protein concentration with reference to control (Mishra et al. 2008). In addition, leaf extracts obtained from four desert species including Sicyos deppei, Accacia sedillense, Sebastiania adenophora and Lantana camara decreased root growth but stimulated an overall increase in protein synthesis in roots of Zea mays, Phaseolus vulgaris, Cucurbita pepo and Lycopersicon esculentum (Romero-Romero et al. 2002). Due to high protein production in treated algae, it may be inferred that some proteins are leaf extracts responsive and up regulated in high concentrations of bioactive substances.

\section{Conclusion}

One of the main objectives of algal biotechnology is to enhance production or accumulation of commercially important bioproducts. In the present work, we examined the effects of aqueous extracts of eucalyptus and elderberry leaves on growth pattern and $\beta$-carotene production in $D$. salina. The data strongly suggested that leaf extracts produced from both species cause stress and inhibited growth of algal cells. However, because of more inhibitory activity of eucalyptus extracts respect to elderberry, higher physiological and metabolic changes of Dunaliella were detected in response to eucalyptus leaf extracts. Despite the inhibition of cell growth by leaf extracts, the alga can well tolerate high levels of the extracts. Removing the leaf extracts from cell suspensions cause the resumption of growth and decrease in fresh weight of Dunaliella cells, which further confirm the suggestion. Dunaliella cultivation under leaf extracts treatment enhances high accumulation of $\beta$-carotene, proteins, and carbohydrates. Stimulation of $\beta$-carotene biosynthesis that occurred in response to leaf extracts is considered as an exclusive strategy for Dunaliella cells to tolerate stress. Increased sugar content can be indicated establishment of osmotic adjustment in the cells exposed to leaf extracts. It is also likely that 

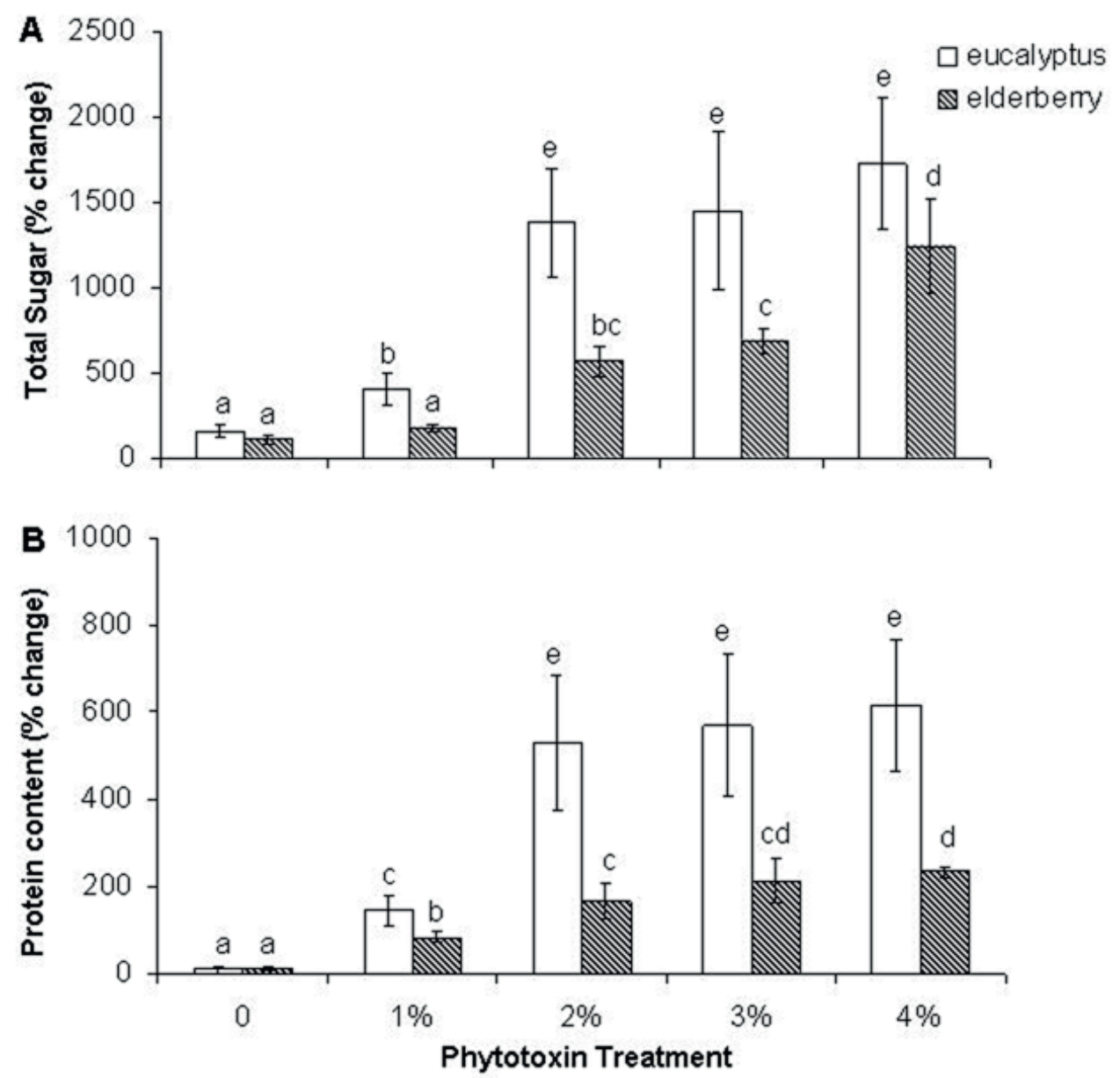

Figure 5. Changes in total sugar (A) and protein concentration (B) of Dunaliella salina cells, after exposure to different concentrations of extracts of eucalyptus and elderberry leaves. The values are expressed as percentage change between initial values of time zero and $48 \mathrm{~h}$ after leaf extracts treatment. Results are mean \pm SD of three independent experiments from independent flasks. Different letters indicate significant differences between the various treatments at $\mathrm{P}<0.05$ according to the Duncan test.

the increased proteins in response to the leaf extracts are stress proteins that are related to self-protection mechanisms. Therefore, leaf extracts-tolerance mechanisms in D. salina are associated with physiological and metabolic adjustments by directing carbon flux to the synthesis of osmolytes and secondary antioxidant molecules such as sugars and $\beta$-carotene, which increase algae tolerance to growth inhibitors. Hyperaccumulation of $\beta$-carotene and carbohydrates induced by leaf extracts in Dunaliella can play an important role in its commercial and biotechnological applications. Thus, the biologically active substances holds potential to be a new solution and a promising strategy for improving Dunaliella cultivation to enhance production of $\beta$-carotene and some particular metabolites. These beneficial attributes of $D$. salina distinctly reveal that the alga possesses particular inherent capabilities including the extraordinary physiological and metabolic plasticity, which allows D. salina to survive in unstable environments and make its industrial and biotechnological potential.

\section{Acknowledgements}

We would like to thank the USB Deputy of Research for funding to S.M.Ghasemi as grants for M.Sc. research projects.

\section{References}

Andersen RA. 2005. Algal Culturing Techniques. Burlington, Elsevier Academic press.

Arnon D. 1949. Copper enzymes in isolated chloroplasts: polyphenoloxidase in Beta vulgaris. Plant Physiology 24: 1-15.

Avron M, Ben-Amotz A. 1992. Dunaliella: Physiology, biochemistry and biotechnology. Boca Raton, CRC Press.

Azania AAPM, Azania CAM, Alives PLCA, et al. 2003. Allelopathic plants. 7. Barley (Hordeum vulgare L.). Allelopathy Journal 11: 1-20.

Baerr JN, Thomas JD, Taylor BG, Rodermel SR, Gray GR. 2005. Differential photosynthetic compensatory mechanisms exist in the immutans mutant of Arabidopsis thaliana. Physiologia Plantarum 124: 390-402.

Bajwa R, Nazi I. 2005. Allelopathic effects of Eucalyptus citriodora on growth, nodulation, and AM colonization of Vigna radiata (L.) Wilczek. Allelopathy Journal 15: 237-246 


\section{Metabolic responses and $\beta$-carotene production by the unicellular green alga Dunaliella salina exposed to leaf extracts}

Bao JS, Cai YZ, Sun M, Wang G, Corke H. 2005. Anthocyanins, flavonols, and free radical scavenging activity of chinese bayberry (Myrica rubra) extracts and their color properties and stability. Journal of Agricultural Food Chemistry 53: 2327-2332.

Ben-Amotz A. 1996. Effect of low temperature on the stereoisomer composition of $\beta$-carotene in the halotolerant alga, Dunaliella bardawil (Chlorophyta). Journal of Phycology 32: 272-275.

Ben-Amotz A, Avron M. 1983. On the factors which determine massive b-carotene accumulation in the halo-tolerant alga Dunaliella bardawil. Plant Physiology 72: 593-597.

Ben-Amotz A, Katz A, Avron M. 1982. Accumulation of $\beta$-carotene in halotolerant algae: purification and characterization of $\beta$-carotenerich globules from Dunaliella bardawil (Chlorophyceae). Journal of Phycology 18: 529-537.

Ben-Amotz A, Lers A, Avron M. 1988. Stereoisomers of $\beta$-carotene and phytoene in alga Dunaliella bardawil. Plant Physiology 86: 1286-1291.

Ben-Amotz A, Shaish V, Avron M. 1989. Mode of action of the massively accumulated $\beta$-carotene of Dunaliella bardawil in protecting the alga against damage by excess irradiation. Plant Physiology 91: 1040-1043.

Benzie IFF, Strain JJ. 1996. The ferric reducing ability of plasma (FRAP) as a measure of "antioxidant power": The FRAP assay. Analytical Biochemistry 239: 70-76.

Biswal AK, Pattanayak GK, Pandey SS, Leelavathi S, Reddy VS, Govindjee, Tripaty BC. 2012. Light intensity-dependent modulation of chlorophyll $b$ biosynthesis and photosynthesis by overexpression of chlorophyllide a oxygenase in tobacco. Plant Physiology 159: 433-449.

Bogatek R, Gniazdowska A, Zakrzewska W, Oracz K, Gawronski SW. 2006. Allelopathic effect of sunflower extracts on mustard seed germination and seedling growth. Biologia Plantarum 50: 156-158.

Bohnert HJ, Sheveleva E. 1998. Plant stress adaptations-making metabolism to move. Current Opinion in Plant Biology 1: 267-274.

Borowitzka MA. 1995. Microalgae as a source of pharmaceuticals and other biologically active compounds. Journal of Applied Phycology 7: 3-15.

Borowitzka MA, Borowitzka LJ. 1988. Limits to growth and carotenogenesis in laboratory and large-scale outdoor cultures of $D$. salina. In: Stadler T, Mollion J, Berdus MC, Karamanos Y, Morvan H, Christiane D. (eds.) Algal Biotechnology. Barking, Elsevier Applied Science. p 139-150.

Bradford MM. 1976. A rapid and sensitive method for the quantitation of microgram quantities of protein utilizing the principle of protein-dye binding. Analytical Biochemistry 72: 248-254.

Bray EA. 1993. Molecular responses to water deficit. Plant Physiology 103: 1035-1040.

Campo JA, García-González M, Guerrero MG. 2007. Outdoor cultivation of microalgae for carotenoid production: current state and perspectives. Applied Microbiology and Biotechnology 74: 1163-1174.

Chang CC, Yang MH, Wen HM, Chern JC. 2002. Estimation of total flavonoid content in propolis by two complementary colorimetric methods. Journal of Food and Drug Analysis 10: 178-182.

Christina M, Rouifed S, Puijalon S, et al. 2015. Allelopathic effect of a native species on a major plant invader in Europe. The Science of Nature 102:12.

Cowan AK, Rose PD, Horne LG. 1992. Dunaliella salina a model system for studying the response of plant cells to stress. Journal of Experimental Botany 43: 1535-1547.

Demmig-Adams B, Gilmore AM, Adams WW. 1996. Carotenoids 3: In vivo functions of carotenoids in higher plants. FASEB Journal 10: 403-412.

Dufosse L, Galaup P, Yaron A, et al. 2005. Microorganisms and microalgae as sources of pigments for food use: a scientific oddity or an industrial reality? Trends in Food Science and Technology 16: 389-406.

Durán-Serantes B, González L, Reigosa MJ. 2002. Comparative physiological effects of three allelochemicals and two herbicides on Dactylis glomerata. Acta Physiologiae Plantarum 24: 385-392.

Eggink LL, LoBrutto R, Brune DC, et al. 2004. Synthesis of chlorophyll b: localization of chlorophyllide $a$ oxygenase and discovery of a stable radical in the catalytic subunit. BMC Plant Biology 4: 5-21.

Eggink LL, Park H, Hoober JK. 2001. The role of chlorophyll b in photosynthesis: hypothesis. BMC Plant Biology 1: 2-9.

Einali A, Shariati M. 2012. Effects of n-propyl gallate on photosynthesis and physiological parameters in Dunaliella salina are affected by stressful conditions. Brazilian Journal of Plant Physiology 24: 193-202.
Einali A, Shariati M. 2015. Effects of propyl gallate on photosystem II efficiency in Dunaliella bardawil under high illumination as investigated by chlorophyll fluorescence measurements. Theoretical and Experimental Plant Physiology 27: 61-73.

Einali A, Valizadeh J. 2015. Propyl gallate promotes salt stress tolerance in green microalga Dunaliella salina by reducing free radical oxidants and enhancing b-carotene production. Acta Physiologiae Plantarum 37: 83.

El-Khawas SA Shehata MM. 2005. The Allelopathic Potentialities of Acacia nilotica and Eucalyptus rostrata on Monocot (Zea mays L.) and Dicot (Phaseolus vulgaris L.) Plants. Biotechnology 4: 23-34.

Florentine SK, Fox JED. 2003. Allelopathic effects of Eucalyptus victrix L. on Eucalyptus species and grasses. Allelopathy Journal 11: 77-83.

Fresco P, Borges F, Diniz C, Marques MPM. 2006. New insights on the anticancer properties of dietary polyphenols. Medicinal Research Reviews 26: 747-766.

García-Gomez C, Parages ML, Jimenez C, Palma A, Mata MT, Segovia M. 2012. Cell survival after UV radiation stress in the unicellular chlorophyte Dunaliella tertiolecta is mediated by DNA repair and MAPK phosphorylation. Journal of Experimental Botany 63: 5259-5274.

Gardner RAW. 2007. Investigating the environmental adaptability of promising subtropical and cold-tolerant eucalypt species in the warm temperate climate zone of KwaZulu-Natal, South Africa. South Hemisphere Forestry Journal 69: 27-38.

Gill PK, Sharma AD, Singh P, Bhullar SS. 2001. Effect of various abiotic stresses on the growth, soluble sugars and water relations of sorghum seedlings grown in light and darkness. Bulgarian Journal of Plant Physiology 27: 72-84.

Golldack D, Deitz K, Gimmler H. 1995. The effect of sudden salt stress on protein synthesis in the green alga Dunaliella salina. Journal of Plant Physiology 146: 508-514.

Haghjou MM, Colville L, Smirnoff N. 2014. The induction of menadione stress tolerance in the marine microalga, Dunaliella viridis, through cold pretreatment and modulation of the ascorbate and glutathione pools. Plant Physiology and Biochemistry 84: 96-104.

Hanson AD. 1980. Interpreting the metabolic responses of plants to water stress. Horticultural Science 15: 623-629.

Kupidłowska E, Gniazdowska A, Stępień J, et al. 2006. Impact of sunflower (Helianthus annuus L.) extracts upon reserve mobilization and energy metabolism in germinating mustard (Sinapis alba L.) seeds. Journal of Chemical Ecology 32: 2569-2583.

Li Z, Keasling JD, Niyogi KK. 2012. Overlapping photoprotective function of vitamin E and carotenoids in Chlamydomonas. Plant Physiology 158: 313-323.

Mccready RM, Guogolz J, Silvtera V, Owens Hs. 1950. Determination of starch and amylose in vegetables. Analytical Chemistry 22: 1156-1160.

Mendes LBB, Vermelho AB. 2013. Allelopathy as a potential strategy to improve microalgae cultivation. Biotechnology for Biofuels 6: 152.

Mersie W, Singh M. 1993. Phenolic acids affect photosynthesis and protein synthesis by isolated leaf cells of velvet-leaf. Journal of Chemical Ecology 19: 1293-1130.

Mishra A, Jha B. 2011. Antioxidant response of the microalga Dunaliella salina under salt stress. Botanica Marina 54: 195-199.

Mishra A, Mandoli A, Jha B. 2008. Physiological characterization and stress-induced metabolic responses of Dunaliella salina isolated from salt pan. Journal of Industrial Microbiology and Biotechnology 35: 1093-1101.

Murthy KNC, Vanitha A, Rajesha J, et al. 2005. In vivo antioxidant activity of carotenoids from Dunaliella salina, a green microalga. Life Science 76: 1381-1390.

Porra RJ, Schafer W, Cmiel E, Katheder I, Scheer H. 1994. The derivation of the formyl-group oxygen of chlorophyll $b$ in higher plants from molecular oxygen. Achievement of high enrichment of the 7-formylgroup oxygen from ${ }^{18} \mathrm{O} 2$ in greening maize leaves. European Journal of Biochemistry 219: 671-679.

Prado FE, Boero C, Gallardo M, Gonzalez JA. 2000. Effect of $\mathrm{NaCl}$ on germination, growth, and soluble sugar content in Chenopodium quinoa wild seeds. Botanica Bulletin Academia Sinica 41: 27-34.

Putnam AR, Tang CS. 1986. The science of allelopathy. New York, John Wiley and Sons. 
Raja R, Hemaiswarya S, Rengasamy R. 2007. Exploitation of Dunaliella for $\beta$-carotene production. Applied Microbiology and Biotechnology 74: 517-523.

Rice-Evans CA, Miller NJ, Bolwell PG, Bramley PM, Pridham JB. 1995. The relative antioxidant activities of plant-derived polyphenolic flavonoids. Free Radical Research 23: 375-383.

Romero-Romero T, Luisa Anaya A, Cruz-Ortega R. 2002. Screening for effects of phytochemical Variability on cytoplasmic protein synthesis Pattern of crop plants. Journal of Chemical Ecology 28: 617-629.

Rosso D, Ivanov AG, Fu A, et al. 2006. IMMUTANS does not act as a stress-induced safety valve in the protection of the photosynthetic apparatus of Arabidopsis during steady-state photosynthesis. Plant Physiology 142: 574-585

Rothschild LJ, Mancinelli RL. 2001. Life in extreme environments. Nature 409: 1092-1101.

Salguero A, Morena B, Vigara J, Vega JM, Vilchez C, Leon R. 2003. Carotenoids as protective response against oxidative damage in Dunaliella bardawil. Bimolecular Engineering 20: 249-253.

Sasikumar K, Vijayalakshmi C, Parthiban KT. 2002. Allelopathic effects of eucalyptus on blackgram (Phaseolus mungo L.). Allelopathy Journal 9: 205-214.

Schoen M. 1988. Cell counting. In: Lobban C, Champan D, Kermer BP. (ed.s) Experimental phycology. Cambridge, Cambridge University Press. p. 16-22.

Shahbazi M, Gilbert M, Laboure AM, Kuntz M. 2007. Dual role of the plastid terminal oxidase in tomato. Plant Physiology 145: 691-702.

Singh KP, Singh K. 1993. Influence of stimulated water stress on free praline accumulation in Triticum aestivum L. (wheat). Indian Journal of Plant Physiology 26: 319-321

Singh V, Toky OP. 1995. Biomass and net primary productivity in leucaena, acaciaand eucalyptus, short-rotation, high-density (energy) plantations in arid India. Journal of Arid Environment 31: 301-309.

Singleton VL, Orthofer R, Lamuela-Raventos RM. 1999. Analysis of total phenols and other oxidation substrates and antioxidants by means of Folin-Ciocalteau reagent. Methods in Enzymology 299: 152-178.

Spolaore P, Joannis-Cassan C, Duran E, Isam bert A. 2006. Commercial applications of microalgae. Journal of Bioscience and Bioengineering 101: 87-96.

Swain T. 1977. Secondary compounds as protective agents. Annual Review in Plant Physiology 28: 479-501.

Tanaka R, Koshino Y, Sawa S, Ishiguro S, Okada K, Tanaka A. 2001. Overexpression of chlorophyllide a oxygenase (CAO) enlarges the antenna size of photosystem II in Arabidopsis thaliana. Plant Journal 26: 365-373

Tian JY, Yu J. 2009. Changes in ultrastructure and responses of antioxidant systems of algae (Dunaliella salina) during acclimation to enhanced ultraviolet-B radiation. Journal of Photochemistry and Photobiology B: Biology 97: 152-160.

Vierling V. 1991. The roles of heat shock proteins in plants. Annual Review in Plant Physiology and Plant Molecular Biology 42: 579-620.

Weston LA, Duke SO. 2003. Weed and crop allelopathy. Critical Review in Plant Science 22: 367-389.

Weston LA, Yang X, Scheffler B. 2002. Gene regulation of bioactive root exudates produced by Sorghum sp. In: Fujii Y, Hiradate S, Araya H. (eds.) Abstracts III World Congress on Allelopathy: Challenge for the New Millenium. Abstract No.S05-07. Tsukuba, Third World Congress on Allelopathy Local Organizing Committee, National Institute for Agro-Environmental Sciences. p 76.

Yilancioglu K, Cokol M, Pastirmaci I, Erman B, Cetiner S. 2014. Oxidative stress is a mediator for increased lipid accumulation in a newly isolated Dunaliella salina strain. PLOS One 9: e91957. doi: 10.1371/journal. pone.0091957.

Yu X, Chen L, Zhang W. 2015. Chemicals to enhance microalgal growth and accumulation of high-value bioproducts. Frontiers in Microbiology 6: 56 . 